\title{
SISI: A New Device for In Situ Incubations at the Ocean Surface
}

\author{
Janina Rahlff ${ }^{1, *}$ (D), Christian Stolle ${ }^{1,2}$ and Oliver Wurl ${ }^{1}$ \\ 1 Institute for Chemistry and Biology of the Marine Environment (ICBM), Carl-von-Ossietzky-University \\ Oldenburg, Schleusenstraße 1, 26382 Wilhelmshaven, Germany; christian.stolle2@uni-oldenburg.de(C.S.); \\ oliver.wurl@uni-oldenburg.de(O.W.) \\ 2 Leibniz-Institute for Baltic Sea Research Warnemuende (IOW), Seestraße 15, 18119 Rostock, Germany \\ * Correspondence: janina.rahlff@uni-oldenburg.de or janinarahlff@gmail.com; Tel.: +49-4421-944164
}

Received: 4 August 2017; Accepted: 21 September 2017; Published: 26 September 2017

\begin{abstract}
The sea-surface microlayer (SML) forms the uppermost boundary layer between atmosphere and ocean, and has distinctive physico-chemical and biological features compared to the underlying water. First findings on metabolic contributions of microorganisms to gas exchange processes across the SML raised the need for new in situ technologies to explore plankton-oxygen turnover in this special habitat. Here, we describe an inexpensive research tool, the Surface In Situ Incubator (SISI), which allows simultaneous incubations of the SML, and water samples from $1 \mathrm{~m}$ and $5 \mathrm{~m}$, at the respective depths of origin. The SISI is deployed from a small boat, seaworthy up to $5 \mathrm{bft}$ (Beaufort scale), and due to global positioning system (GPS) tracking, capable of drifting freely for hours or days. We tested the SISI by applying light/dark bottle incubations in the Baltic Sea and the tropical Pacific Ocean under various conditions to present first data on planktonic oxygen turnover rates within the SML, and two subsurface depths. The SISI offers the potential to study plankton-oxygen turnover within the SML under the natural influence of abiotic parameters, and hence, is a valuable tool to routinely monitor their physiological role in biogeochemical cycling and gas exchange processes at, and near, the sea surface.
\end{abstract}

Keywords: sea-surface microlayer; net community production; respiration; plankton; neuston; oxygen; air-sea boundary; gas exchange; floating chamber; in situ incubator

\section{Introduction}

The sea-surface microlayer (SML) at the air-sea interface spans two-thirds of the global surface area. Despite having a maximum thickness of $1 \mathrm{~mm}$, the SML has profoundly different physico-chemical and biological characteristics compared to the underlying water column [1-3]. In addition, due to the accumulation of organic matter and surface-active molecules [4,5], the SML constitutes a unique biofilm-like habitat for microorganisms [3,6]. Life within the SML is heavily influenced by a range of "extreme" conditions such as enhanced solar and ultraviolet (UV) radiation [7-9], strong wind-wave dynamics [10,11] and the accumulation of pollutants [12]. Heterotrophic microbes in particular benefit from the enrichment of organic substrates, allowing them to thrive and form distinctive communities within the SML compared to the underlying water $[13,14]$. Increased abundance of heterotrophic microorganisms within the SML is a typical observation [15], and is accompanied by remarkably enhanced respiratory activity $[16,17]$.

The light/dark bottle incubation technique is the primary approach used to measure planktonic production and respiration in surface water [18]. For assessment of the plankton's metabolic potential, it is common practice to incubate sea water samples in closed containers on deck [19], although this method is less compatible with adequate temperature control, especially in tropical regions [20]. Other approaches involve incubations in bottles attached to a conductivity-temperature-depth (CTD) 
device [21], in floating racks attached to the mother-ship [9,22], or incubations are replaced by performing consecutive water sampling over several hours or days from the same depth [23]. Although a practical incubation method for assessing in situ oxygen $\left(\mathrm{O}_{2}\right)$ turnover in SML samples exists [24], an incubation apparatus that additionally allows for incubations at two reference depths in subsurface layers is missing to date.

Therefore, the Surface In Situ Incubator (SISI) was built to enable in situ bottle incubations at the oceanic air-sea interface, and at two near-surface depths (1 and $5 \mathrm{~m})$ for the purpose of comparison. It was designed on the basis of a similar incubation apparatus for coastal work under calm conditions [24]. Oceanic data on metabolic processes at the SML are scarce, due to the non-existence of incubation devices for routine and reliable deployments. The SML is a crucial but understudied component for air-sea exchange processes, for example, of climate relevant gases or organic matter. For instance, phytoplankton-derived surfactants accumulating within the SML are known to influence gas exchange [25]. Moreover, the direct metabolic control of gas exchange by the SML microorganisms has been previously suggested [26,27]. Such findings demonstrate that biology-driven gas turnover within the SML requires further attention, and stresses the need for new methodologies to improve our knowledge on the SML's biogeochemical nature and climate-related implications.

The aim of this technical note is to describe the SISI as a new and inexpensive research tool for oceanographers to carry out routine incubation studies in the SML and the near surface layer. We discuss first, results on planktonic $\mathrm{O}_{2}$ turnover obtained from the Baltic Sea and the Pacific Ocean using the SISI. We additionally present a range of other possible applications in the field of environmental science.

\section{Materials and Methods}

\subsection{Description of the Research Tool}

The SISI has a total weight of $\sim 8 \mathrm{~kg}$ and consists of three rectangular frames of equal size $(54 \mathrm{~cm}$ $\times 19 \mathrm{~cm} \times 5 \mathrm{~cm}$ ) made of polymethyl methacrylate (PMMA). The top frame floats $1-2 \mathrm{~cm}$ underneath the sea surface, the middle frame at $1 \mathrm{~m}$ depth, and the bottom frame at $5 \mathrm{~m}$ depth (Figure 1 and Supplement Video S1: Deployment and operation of the SISI). On both short sides of each frame, a metal bracket with two holes is mounted. Through these holes, ropes with a thickness of $3.2 \mathrm{~mm}$ are bowline-knotted to connect the four corners of the three frames with each other. Only on the top frame are ropes fixed to the bracket with shackles, which are additionally secured with cable ties. The bottom frame is weighted with two bricks $(22 \mathrm{~cm} \times 10 \mathrm{~cm} \times 5 \mathrm{~cm})$ attached to the underside of the frame. Each frame consists of a holder for eight test tubes, i.e., the inner side of the frame itself contains eight holes with a diameter of $25 \mathrm{~mm}$. The test tubes (diameter $=22 \mathrm{~mm}$, length $=200 \mathrm{~mm}$ ) used are made of borosilicate glass type 3.3, have a wall thickness of $1.8 \mathrm{~mm}$, a volume of $\sim 50 \mathrm{~mL}$, and feature a ground glass joint (Carl Roth, Karlsruhe, Germany). Glass bottles have been associated with metal contaminations affecting primary production [28], but according to the manufacturer's instruction, the DURAN ${ }^{\circledR}$ SIMAX material is inert and interactions between the treated glass surface and medium can be ruled out. For dark incubations, test tubes are wrapped with black polyvinyl chloride (PVC) electrical tape. Tubes positioned in the holder are affixed in the frame by gently screwing a mobile plastic plank $(48 \mathrm{~cm} \times 5 \mathrm{~cm} \times 0.6 \mathrm{~cm})$ tightly on top of the lids using lock nuts on three bolts. Foam material is glued on the inner side of the planks for shock protection and to prevent damage of test tubes. The frames are designed so they do not produce shade on the tubes. Within the frame, the test tubes are placed in a horizontal orientation, which is of particular importance in the incubation of the SML samples. The top frame floats at the water surface to mimic in situ incubation conditions at the SML, e.g., strong solar irradiance and temperature fluctuations. The SISI drifts freely with the current or is moored with an anchor. The floatation of the top frame is achieved by mounting four floats with shackles to its edges. On the top frame, a flashlight can be mounted to facilitate visual contact with the SISI during night deployments. 
Underneath the bottom frame, four ropes fixed to the edges end in a large shackle that can be used to attach an anchor, e.g., if the SISI is moored in water of less than $30 \mathrm{~m}$ depth. For drifting freely, a global positioning system (GPS), SPOT Trace (SPOT LLC, Milpitas, CA, USA) allows constant monitoring of the SISI's position if the device is getting out of sight. The GPS device is kept in a waterproof cell phone case mounted on a bracket at the top frame and protruding $30 \mathrm{~cm}$ above the sea surface. The SISI was designed to be deployed from a small boat, and at least two persons are required to fill and fix the test tubes, and to release the SISI into the water. The SISI has been tested up to a sea state of $5 \mathrm{bft}$ (Beaufort scale); even so, its deployment and recovery by a small boat requires calmer sea states for safety reasons. Preparation of the SISI prior to deployment, i.e., filling and fixing of test tubes, takes about two hours, and most of this time must be allocated to SML collection (see next paragraph). Recovery of the SISI can be achieved within $30 \mathrm{~min}$, which includes time to remove and store the test tubes (see Supplement video S1: Deployment and operation of the SISI).

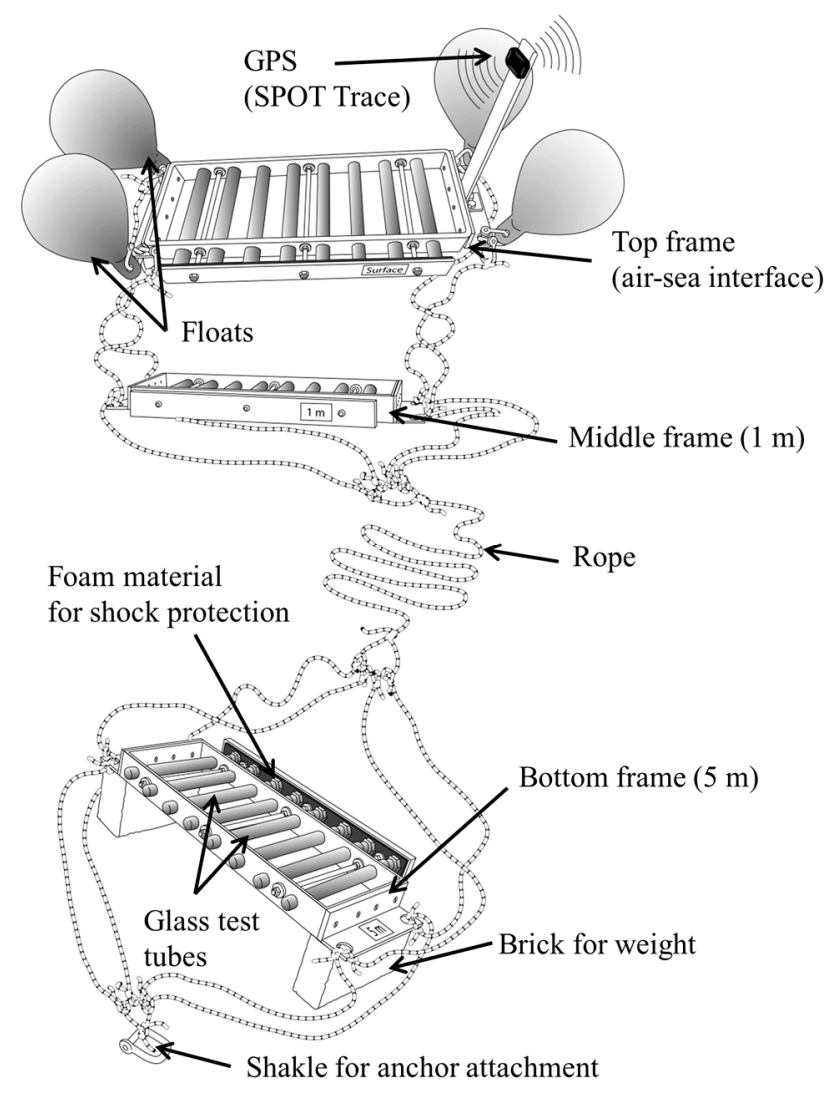

Figure 1. Scheme of the Surface In Situ Incubator (SISI).

\subsection{SISI Deployment and Sample Collection}

We carried out deployments of the SISI in the Baltic Sea in August 2015 (cruise M117 on R/V Meteor) and in the tropical Pacific Ocean in October 2016 (cruise FK161010 on R/V Falkor) (Table 1 and Figure 2). Wind speed $\left(\mathrm{m} \mathrm{s}^{-1}\right)$ was taken from meteorological stations at $34.5 \mathrm{~m}$ and $10 \mathrm{~m}$ height on R/V Meteor and R/V Falkor, respectively. Wind speed from $35.5 \mathrm{~m}$ height was converted to wind speed at $10 \mathrm{~m}$ height by applying the equation as shown in Rahlff et al. [10]. The sea state in bft was calculated from the empirical formula

$$
B=\left(\frac{V}{0.8360 \mathrm{~m} \mathrm{~s}^{-1}}\right)^{\frac{2}{3}}
$$

with $B$ being the Beaufort number, $V$ representing the wind speed in $\mathrm{m} \mathrm{s}^{-1}$ at $10 \mathrm{~m}$ over ground [29]. 
Table 1. Time of incubation of seawater samples, wind speeds and sea states during operation of the Surface In Situ Incubator.

\begin{tabular}{|c|c|c|c|c|c|c|c|c|c|c|c|}
\hline \multirow{2}{*}{ Location } & \multicolumn{2}{|c|}{ Position (Decimal) } & \multirow{2}{*}{$\begin{array}{c}\text { Date (UTC) } \\
\text { Incubation Start }\end{array}$} & \multirow{2}{*}{ Station Name } & \multirow{2}{*}{$\begin{array}{c}\text { Method of } \\
\mathrm{O}_{2} \text { Measurement }\end{array}$} & \multirow{2}{*}{$\begin{array}{l}\text { Incubation } \\
\text { Period (h) }\end{array}$} & \multirow{2}{*}{$\begin{array}{l}\text { Mean Wind } \\
\text { Speed }\left(\mathrm{m} \mathrm{s}^{-1}\right)\end{array}$} & \multirow{2}{*}{ Mean Beaufort } & \multirow{2}{*}{$\begin{array}{l}\text { Max. Wind } \\
\text { Speed }\left(\mathrm{m} \mathrm{s}^{-1}\right)\end{array}$} & \multirow{2}{*}{ Max. Beaufort } & \multirow{2}{*}{ Station Feature } \\
\hline & Latitude (East) & Longitude (North) & & & & & & & & & \\
\hline & & & 03/Aug/2015 11:15 & & Winkler & 12 & 4.3 & 3 & 5.4 & 3 & Coastal, \\
\hline & & & 08/Aug/2015 10:30 & UP5 & & 10.7 & 6.1 & 4 & & 5 & \\
\hline Pacific Ocean & 3.5109 & 137.5965 & 28/Oct/2016 00:34 & Station 9 & Microelectrode & $29.5-35.5$ & 8.1 & 5 & 16.6 & 7 & Open ocean \\
\hline
\end{tabular}




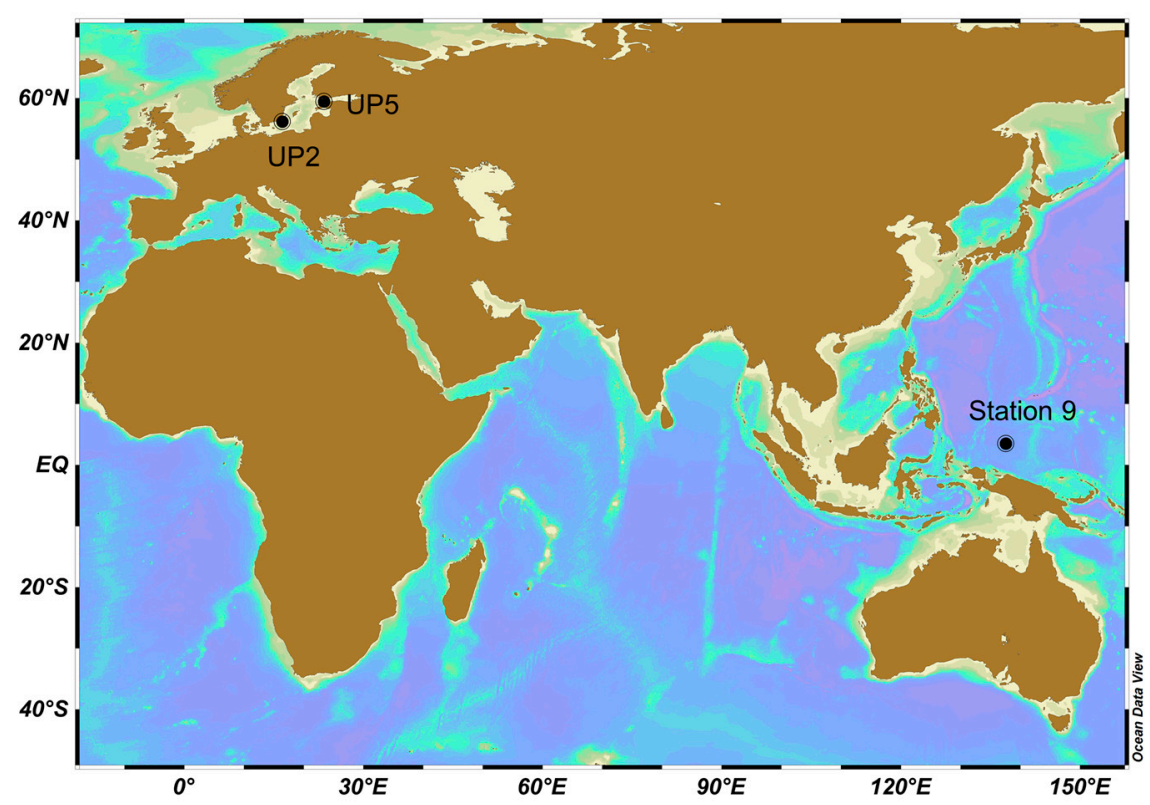

Figure 2. Station map for deployment locations of the Surface In Situ Incubator (SISI). Stations are presented using Ocean Data View [30].

Samples from the SML were collected using a glass plate sampler according to Harvey and Burzell [31], and a modified withdrawal rate of $5-6 \mathrm{~cm} \mathrm{~s}^{-1}$ as suggested by Carlson [32]. The glass plate was cleaned with $70 \%$ ethanol before use and rinsed with sample water. Two to three liters of SML were collected in a $5 \mathrm{~L}$ bottle and transferred into the test tubes by means of a $12 \mathrm{~V}$ gear pump (Barth Elektronik, Lengerich, Germany) and silicon tubing. Water for incubations at $1 \mathrm{~m}$ and $5 \mathrm{~m}$ depths was directly pumped from the respective depths into the test tubes. Each tube was filled to excess with three times its volume to prevent air bubble accumulation inside the test tubes. At each depth, up to four light and four dark incubations were performed, i.e., each frame held four light and four dark test tubes. The test tubes were incubated from 10.7 to $35.5 \mathrm{~h}$ (Table 1). Test tubes for measurement of initial $\mathrm{O}_{2}$ concentrations at each depth were returned to the vessel's laboratory and immediately analyzed.

\subsection{Oxygen Measurements}

After recovery of the test tubes from the SISI, readings on $\mathrm{O}_{2}$ concentration were performed using the commonly applied Winkler titration [33] during the Baltic Sea cruise, or by application of a Clark-type microelectrode (OX-50; Unisense, Aarhus N, Denmark) during the Pacific cruise (Table 1). Linear calibration of the OX-50 sensor was achieved by applying air-saturated seawater $\left(100 \% \mathrm{O}_{2}\right)$ and an anoxic $0.1 \mathrm{M}$ sodium ascorbate solution $\left(0 \% \mathrm{O}_{2}\right)$. The $\mathrm{O}_{2}$ concentration for the $100 \%$ signal was based on the salinity and temperature dependence of $\mathrm{O}_{2}$ solubility [34]. The temperature sensor was calibrated to three random temperatures within the ranges of $0-10^{\circ} \mathrm{C}, 10-30{ }^{\circ} \mathrm{C}$, and $30-50{ }^{\circ} \mathrm{C}$ measured with a glass thermometer.

When measurements were performed with the microelectrode, the incubation was not stopped for all tubes via fixation, as per the Winkler method. Instead, the test tubes were kept at in situ-mimicking conditions, wrapped in a daylight-filtering foil (Lee-298; ZILZ direct, Pulheim, Germany) in a water bath until, and during, analysis. The extra incubation time was later considered when calculating the hourly rate. The temperature of the water bath was monitored during $\mathrm{O}_{2}$ measurements by using an additional sensor (TP-200; Unisense, Aarhus N, Denmark). All $\mathrm{O}_{2}$ readings were corrected for temperature if the temperature in the water bath was different from the temperature during calibration of the OX-50 (see Supplement Note 1: Microelectrode temperature correction). 
$\mathrm{O}_{2}$ concentration was measured at the start ( $n=2$ in the Baltic Sea, $n=3$ in the Pacific Ocean) and end of the incubation period ( $n=3$ in the Baltic Sea, $n=4$ in the Pacific Ocean) after recovery of the SISI. Constant stirring with a magnetic bar and complete submersion of the sensor ensured homogenous distribution of $\mathrm{O}_{2}$ in the test tubes during measurements. After signal stabilization, the $\mathrm{O}_{2}$ concentration was recorded for $90 \mathrm{~s}$, from which the mean $\mathrm{O}_{2}$ concentration was calculated. Rates of net community production (NCP) from light tubes, and respiration (R) from dark tubes, were defined as the difference in $\mathrm{O}_{2}$ concentration between the start and end time points in the light and dark incubations, respectively, and were converted to $\mu \mathrm{mol} \mathrm{O}_{2} \mathrm{~L}^{-1} \mathrm{~h}^{-1}$ by dividing $\mathrm{O}_{2}$ concentration changes by the period of incubation (Table 1).

\subsection{Statistical Analysis}

A few outliers were removed from the original data set, which corresponds to the number of test tubes as mentioned above. Removal of outliers was based on the Dixon test, which is appropriate for small sample sizes, at the 95\% significance level using the "outliers" package in $\mathrm{R}$ (version 3.3.2, Supplement Data S1: Rcode outlier test and dataset, [35]). For larger sample sizes $(n>20)$, the normal distribution of the data is an important requirement for this test, which has not been considered here due to the small number of observations. Outliers are indicated in blue in Figure 3. After outlier removal, the number of replicates was $n=2-3$ for station UP2 and station UP5, and $n=3-4$ for station 9. The limited number of replicates after outlier removal ( $n=2$ in some cases) precluded statistical analyses for differences in R, and NCP, between different depths at the Baltic Sea stations, and we applied more test tubes on the subsequent Pacific cruise. A non-parametric Kruskal-Wallis test with a post-hoc Dunn's multiple comparison test was performed to check for significant differences (95\% significance level) of mean $\mathrm{O}_{2}$ production rates between depths at Pacific station 9 using GraphPad Prism version 5.00 (GraphPad Software, San Diego, CA, USA). The complete data set has been deposited in the PANGAEA database [36].

\section{Results and Discussion}

For demonstrating that incubations with the SISI lead to reasonable results of $\mathrm{O}_{2}$ turnover rates at different incubation depths, we applied the device at three stations of two different marine systems; in the enclosed Baltic Sea and in the open Pacific Ocean.

For the coastal Baltic Sea stations UP2 and UP5, we observed stronger differences in $\mathrm{O}_{2}$ turnover rates between NCP and R (Figure 3a,b). NCP rates were generally positive in $1 \mathrm{~m}$ and $5 \mathrm{~m}$ water depth incubations in the Baltic Sea assuming the presence of photosynthesizing organisms in coastal proximity. At station UP5, we even measured a positive NCP rate for the SML, which matches the observation that phytoneuston productivity can sometimes be enhanced in sheltered regions [37,38].

In the tropical Pacific Ocean, rates of NCP and R were very similar at each depth (Figure 3c). Compared to the Baltic Sea, all samples in the tropical Pacific Ocean showed $\mathrm{O}_{2}$ consumption. Nearly equal negative rates of NCP and R, as those observed for station 9, might indicate a lack of primary production or heterotrophic processes dominating $\mathrm{O}_{2}$ turnover, which is typical for the oligotrophic Pacific open ocean [39]. According to the Kruskal-Wallis test, no significant differences of mean $\mathrm{O}_{2}$ turnover rates among the different depths could be observed for station 9, with one exception: dark-incubated samples from the SML, and the $5 \mathrm{~m}$ water depth, showed a weak significant difference (Dunn's test, $p<0.05$ ) in respiration rates. 
(a)

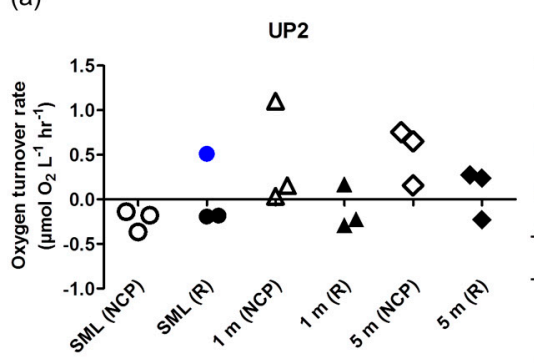

(b)

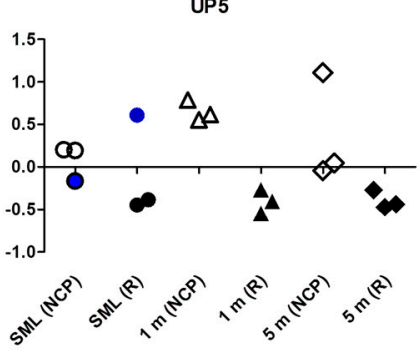

(c)

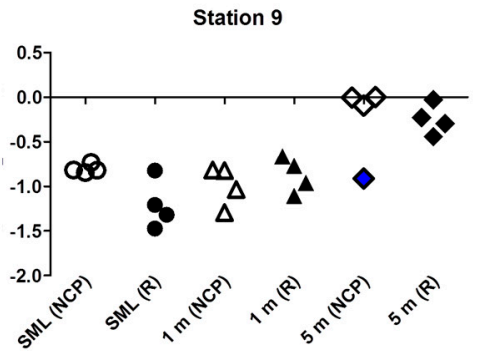

Figure 3. Oxygen turnover rates per hour recorded using the SISI and the light/dark bottle incubation technique for stations in the Baltic Sea $(\mathbf{a}, \mathbf{b})$ and the Pacific Ocean (c). Shown are single replicates and all outliers (blue symbols). $\mathrm{NCP}=$ net community production, $\mathrm{R}=$ respiration, $\mathrm{SML}=$ sea-surface microlayer.

Most importantly for demonstrating the benefit of using the SISI, the absolute $\mathrm{O}_{2}$ turnover rates in the Baltic Sea and Pacific Ocean were in a range comparable with those previously reported. Namely, $4.9 \pm 0.23 \mathrm{mmol} \mathrm{O}_{2} \mathrm{~m}^{-3} \mathrm{~d}^{-1}$ and $3.3 \pm 0.15 \mathrm{mmol} \mathrm{O}_{2} \mathrm{~m}^{-3} \mathrm{~d}^{-1}$, for surface water $<10 \mathrm{~m}$ in coastal, and open ocean areas, respectively [18]. At all three stations, both in the Baltic Sea and the Pacific open ocean, SML samples showed the strongest respiration rates in dark incubations compared to underlying water depths; which is in line with previous observations on enhanced heterotrophic respiration within the SML $[16,17]$.

Previously mentioned containment errors, e.g., by prevention of grazing pressure and the associated increase of bacterial abundances in closed-bottle incubations [40], could not be circumvented by using the SISI. Containment errors supporting increased bacterial cell numbers might be especially relevant for SML samples, which are particularly substrate-rich and, thus, attractive to bacteria [6]. Our observations fit with findings from Pomeroy, Sheldon and Sheldon [40] of a $23 \%$ increase in bacterial cell numbers in dark-incubated SML samples from the start to end of the incubation period for Pacific station 9 (Supplement Data S2: Cell counts St.9 SISI). One reason for this might be that SML microorganisms in closed-bottle incubations particularly benefit from low turbulence and minimal impact from waves and wind, which are crucial factors that would naturally affect them $[10,11]$. We suggest that incubation times should be adjusted to the minimum, which produces reasonable rates of $\mathrm{O}_{2}$ turnover but reduces containment errors, such as enormous increases in cell numbers. It has been argued that primary production should be measured within a $24 \mathrm{~h}$ diel cycle, because abundant phytoplankton cells have a lifespan limited to hours or days [20], and the likelihood for containment-associated errors increases with time. However, we extended the incubation periods $>24 \mathrm{~h}$ due to previously reported low productivity in the oligotrophic Pacific Ocean [39] and assumed little changes of $\mathrm{O}_{2}$ concentration from the start to the end of the incubation period.

Furthermore, incubations using the SISI account for effects from temperature, whose fluctuations are more extreme within the SML [37], but also for impacts from solar and partial UV radiation on SML organisms [7,9]. Even if the construction of a rigid upper frame is not ideal regarding its conformation to the wave crests resulting in unwanted elevations above and submersions beneath the surface, we assume that the effects due to variations in light exposure will, on average, balance each other out. Although the upper frame might temporarily sink to a depth of approximately $5 \mathrm{~cm}$ due to wavy sea conditions and the rigid make-up of the upper frame, light conditions will be very similar to those at the immediate air-sea interface, but profoundly different from $1 \mathrm{~m}$. According to the Beer-Lambert law, and applying a typical oceanic light attenuation coefficient of $0.0384 \mathrm{~m}^{-1}$ [41], losses of irradiances at $5 \mathrm{~cm}$ are minor compared to $1 \mathrm{~m}$ depth, namely $0.2 \%$ and $3.8 \%$, respectively.

The test tubes made of borosilicate glass type 3.3 allowed for transmission of UV radiation in the $310-400 \mathrm{~nm}$ wavelength range, whereas UV radiation in the lower $280-310 \mathrm{~nm}$ range was blocked (manufacturer's specification). Alternatively, customer-made test tubes of quartz glass can be used to 
cover a wider range of UV radiation, but could not be used in this study due to the high costs of these tubes. To make intermediate readings with the microelectrode during an incubation period, test tubes with a resealable rubber septum as a lid could be used.

The advantages and disadvantages of different methodologies to measure dissolved $\mathrm{O}_{2}$ concentrations have been extensively compared and discussed in the literature [42-44]. With Winkler titration, we used a highly accurate standard method that was, however, not very field-friendly and, as it was conducted manually, required experienced analysts to obtain high quality data. Clark-type microelectrodes require thorough calibration and temperature compensation. Using both analytical approaches, incubations with the SISI led to reasonable results on plankton metabolism in terms of $\mathrm{O}_{2}$ turnover in surface water [18] of the two different marine systems.

The SISI is a new tool that allows in situ incubations in surface water and at the SML; the immediate boundary between the atmosphere and hydrosphere. The SISI has several advantages:

(1) It leads to reasonable results on $\mathrm{O}_{2}$ turnover rates of plankton communities as reported here.

(2) It allows for in situ bottle incubations close to the SML and in near-surface layers.

(3) Incubation periods up to several days are possible.

(4) The SISI is applicable under typical oceanic conditions (tested and recommended for sea states up to $5 \mathrm{bft}$ ), and under these conditions shallow submersion of the upper frame (approximately $5 \mathrm{~cm}$; see Supplement Video S1: Deployment and operation of the SISI) ensures incubation under surface radiation.

(5) It is inexpensive with material costs of approximately \$950 USD, which includes 33 test tubes.

(6) It allows applications without environmental impacts.

(7) It can be deployed by being anchored in shallow water, or GPS-tracked in the open ocean, allowing for other operations on the R/V.

However, the deployment of the SISI requires three hours of ship time and the operation of a small boat and coxswain, as well as two additional persons for the deployment. Despite the SISI's seaworthiness up to $5 \mathrm{bft}$ (Table 1), temporarily even standing short periods of $7 \mathrm{bft}$ (station 9), its deployment and recovery require moderate weather conditions with sea states $\leq 4 \mathrm{bft}$ (wind speeds of 5.5-8 $\mathrm{m} \mathrm{s}^{-1}$ ) for the operation of a small boat. In oligotrophic water, long incubation periods of up to $48 \mathrm{~h}$ might be required to observe appreciable changes in $\mathrm{O}_{2}$ concentration between the start and end of the incubation. Taking all these factors into account, the SISI is a useful device for routine assessment of planktonic $\mathrm{O}_{2}$ turnover rates within the SML and comparative near-surface depths, which are poorly described in the literature. In addition, the SISI and the test tube volume of $\sim 50 \mathrm{~mL}$ allow for other parameters to be assessed such as microbial cell counts and community composition. We suggest using the SISI for long-term monitoring studies, for instance, during different seasons, which could be useful to improve biogeochemical, or gas exchange models of a defined area.

Possible improvements for a future version of the SISI could include larger frames to allow for a higher number of replicates (more test tubes) to be installed, and to facilitate incubations of larger sample volumes for more analyses to be made (e.g., measurements of pigment composition and concentration). Although it is of strong interest to study processes within the SML as close to in situ conditions as possible, the here presented SISI does not allow for incubations of the SML in its natural integrity and surface-to-volume ratio, i.e., as a thin film in atmospheric contact. Technically, it is very challenging to sample and incubate the SML at exact in situ conditions as this would require expensive technology such as the application of sensor spots. Our design simulates the closest conditions keeping the device practical for routine measurements.

\section{Future Research Directions}

Apart from the purpose presented here, we envision using the SISI for various future applications. Since long-term incubations are possible, the SISI could be applied to study the fate of marine pollutants, which frequently accumulate within the SML [12], and which are probably exposed to different rates 
of photochemical or microbial transformation at different depths. This could be relevant to the study of the biodegradation of oil products forming oil slicks at the sea surface [45], and associated impacts on marine biota and ecosystem functioning [46]. Another application for the SISI might be the incubation of water samples containing microplastics, whose higher abundance in the SML, compared to underlying water, has been recently described [47]. Bacterial colonization of polymer-based materials and biofilm formation [48], as well as microbial degradation of microplastic particles [49], constitute highly topical research areas that could be further investigated using the SISI.

In addition, the photochemical and microbial transformation of dissolved organic matter (DOM), which is enriched in the SML, compared to the underlying water [17], and plays a profound role in marine biogeochemical cycling, could be explored using incubations in the SISI. Photolysis transforms recalcitrant DOM into bioavailable, labile carbon compounds, a process that occurs even at low intensities of visible light [50]. Such labile compounds can be further utilized by heterotrophic microorganisms [51]. On the other hand, labile DOM components under the influence of UV radiation can also undergo crosslinking and, in turn, contribute to the refractory DOM pool [50].

For ecological questions, the SISI could help to elucidate the short-term adaptation potential of bacteria, phyto- and microzoo- plankton when exposed to different temperatures, UV, and light regimes. As sea-surface temperature and UV radiation are predicted to increase with ongoing climate change [52,53], incubation experiments can contribute to a better understanding on how planktonic organisms may adapt to environmental changes and influence food webs in a future ocean.

Supplementary Materials: The following are available online at www.mdpi.com/2077-1312/5/4/46/s1, Supplement Video S1: Deployment and operation of the SISI, Supplement Data S1: R code outlier test and dataset, Supplement Data S2: Cell counts St9 SISI, Supplement Note 1: Microelectrode temperature correction.

Acknowledgments: The described research tool herein was built for use in the Parameterization of the Sea-Surface Microlayer Effect (PASSME) project funded by the European Research Council (ERC) project (grant number GA336408), and we received funds to publish in open access. We thank the captains and crew members of the R/V Meteor (cruise M117) and R/V Falkor (cruise FK161010). We would also like to acknowledge our colleagues at the ICBM workshop for construction of the SISI, as well as M. Ladehoff, L. Oeljeschläger, K. Bird, and M. Ribas-Ribas for their kind assistance during deployment. We are also grateful to R. Baaske for analyzing cell abundances, and S. Trinkler for performing the Winkler analyses. We further thank S. Constable for producing the video, I. Schüller for the scientific illustration of the SISI, and T.-B. Robinson for language editing.

Author Contributions: Oliver Wurl developed the concept of the SISI and together with Janina Rahlff carried out the deployments and sample preparation; Janina Rahlff conducted oxygen measurements, analyzed the data and wrote the first manuscript draft; Christian Stolle contributed to data analysis and experimental design; All authors contributed to writing, discussion and editing of the manuscript.

Conflicts of Interest: The authors declare no conflict of interest. The founding sponsors had no role in the design of the study; in the collection, analyses, or interpretation of data; in the writing of the manuscript, and in the decision to publish the results.

\section{References}

1. Wurl, O.; Ekau, W.; Landing, W.M.; Zappa, C.J. Sea surface microlayer in a changing ocean-A perspective. Elem. Sci. Anth. 2017, 5. [CrossRef]

2. Engel, A.; Bange, H.W.; Cunliffe, M.; Burrows, S.M.; Friedrichs, G.; Galgani, L.; Herrmann, H.; Hertkorn, N.; Johnson, M.; Liss, P.S.; et al. The ocean's vital skin: Toward an integrated understanding of the sea surface microlayer. Front. Mar. Sci. 2017, 4. [CrossRef]

3. Cunliffe, M.; Engel, A.; Frka, S.; Gašparović, B.; Guitart, C.; Murrell, J.C.; Salter, M.; Stolle, C.; Upstill-Goddard, R.; Wurl, O. Sea surface microlayers: A unified physicochemical and biological perspective of the air-ocean interface. Progr. Oceanogr. 2013, 109, 104-116. [CrossRef]

4. Frew, N. The role of organic films in air-sea gas exchange. In The Sea Surface and Global Change; Liss, P.S., Duce, R.A., Eds.; Cambridge Univ. Press: New York, NY, USA, 1997; pp. 121-171.

5. Wurl, O.; Miller, L.; Ruttgers, R.; Vagle, S. The distribution and fate of surface-active substances in the sea-surface microlayer and water column. Mar. Chem. 2009, 115, 1-9. [CrossRef]

6. Wurl, O.; Stolle, C.; Van Thuoc, C.; Thu, P.T.; Mari, X. Biofilm-like properties of the sea surface and predicted effects on air-sea $\mathrm{CO}_{2}$ exchange. Progr. Oceanogr. 2016, 144, 15-24. [CrossRef] 
7. Agogué, H.; Joux, F.; Obernosterer, I.; Lebaron, P. Resistance of marine bacterioneuston to solar radiation. Appl. Environ. Microbiol. 2005, 71, 5282-5289. [CrossRef] [PubMed]

8. Santos, A.L.; Baptista, I.; Lopes, S.; Henriques, I.; Gomes, N.C.; Almeida, A.; Correia, A.; Cunha, A. The UV responses of bacterioneuston and bacterioplankton isolates depend on the physiological condition and involve a metabolic shift. FEMS Microbiol. Ecol. 2012, 80, 646-658. [CrossRef] [PubMed]

9. Carlucci, A.; Craven, D.; Henrichs, S. Surface-film microheterotrophs: Amino acid metabolism and solar radiation effects on their activities. Mar. Biol. 1985, 85, 13-22. [CrossRef]

10. Rahlff, J.; Stolle, C.; Giebel, H.A.; Brinkhoff, T.; Ribas-Ribas, M.; Hodapp, D.; Wurl, O. High wind speeds prevent formation of a distinct bacterioneuston community in the sea-surface microlayer. FEMS Microbiol. Ecol. 2017, 93. [CrossRef] [PubMed]

11. Stolle, C.; Labrenz, M.; Meeske, C.; Jürgens, K. Bacterioneuston community structure in the southern Baltic Sea and its dependence on meteorological conditions. Appl. Environ. Microbiol. 2011, 77, 3726-3733. [CrossRef] [PubMed]

12. Wurl, O.; Obbard, J.P. A review of pollutants in the sea-surface microlayer (SML): A unique habitat for marine organisms. Mar. Pollut. Bull. 2004, 48, 1016-1030. [CrossRef] [PubMed]

13. Cunliffe, M.; Murrell, J.C. Eukarya 18S rRNA gene diversity in the sea surface microlayer: Implications for the structure of the neustonic microbial loop. ISME J. 2010, 4, 455-458. [CrossRef] [PubMed]

14. Franklin, M.P.; McDonald, I.R.; Bourne, D.G.; Owens, N.J.P.; Upstill-Goddard, R.C.; Murrell, J.C. Bacterial diversity in the bacterioneuston (sea surface microlayer): The bacterioneuston through the looking glass. Environ. Microbiol. 2005, 7, 723-736. [CrossRef] [PubMed]

15. Hardy, J.T. The sea-surface microlayer: Biology, chemistry and anthropogenic enrichment. Progr. Oceanogr. 1982, 11, 307-328. [CrossRef]

16. Obernosterer, I.; Catala, P.; Reinthaler, T.; Herndl, G.J.; Lebaron, P. Enhanced heterotrophic activity in the surface microlayer of the Mediterranean Sea. Aquat. Microb. Ecol. 2005, 39, 293-302. [CrossRef]

17. Reinthaler, T.; Sintes, E.; Herndl, G.J. Dissolved organic matter and bacterial production and respiration in the sea-surface microlayer of the open Atlantic and the western Mediterranean Sea. Limnol. Oceanogr. 2008, 53, 122-136. [CrossRef]

18. Robinson, C.; Williams, P.L.B. Respiration and its measurement in surface marine waters. Respir. Aquat. Ecosyst. 2005, 147-180. [CrossRef]

19. Sampou, P.; Kemp, W.M. Factors regulating plankton community respiration in Chesapeake Bay. Mar. Ecol. Prog. Ser. 1994, 110, 249-258. [CrossRef]

20. Marra, J. Approaches to the measurement of plankton production. In Phytoplankton Productivity: Carbon Assimilation in Marine and Freshwater Ecosystems; Williams, P.J.L.B., Thomas, D.N., Reynolds, C.S., Eds.; Chapter 4; Blackwell Science Ltd.: Oxford, UK, 2002; pp. 78-108.

21. Biddanda, B.; Opsahl, S.; Benner, R. Plankton respiration and carbon flux through bacterioplankton on the Louisiana shelf. Limnol. Oceanogr. 1994, 39, 1259-1275. [CrossRef]

22. Williams, P.M.; Carlucci, A.F.; Henrichs, S.; Van Vleet, E.S.; Horrigan, S.G.; Reid, F.M.H.; Robertson, K.J. Chemical and microbiological studies of sea-surface films in the Southern Gulf of California and off the West Coast of Baja California. Mar. Chem. 1986, 19, 17-98. [CrossRef]

23. Sherr, B.F.; Sherr, E.B. Community respiration/production and bacterial activity in the upper water column of the central Arctic Ocean. Deep Sea Res. I 2003, 50, 529-542. [CrossRef]

24. Ignatiades, L. Photosynthetic capacity at the surface microlayer during the mixing period. J. Plankton Res. 1990, 12, 851-860. [CrossRef]

25. Frew, N.M.; Goldman, J.C.; Dennett, M.R.; Johnson, A.S. Impact of phytoplankton-generated surfactants on air-sea gas exchange. J. Geophys. Res. Oceans 1990, 95, 3337-3352. [CrossRef]

26. Conrad, R.; Seiler, W. Influence of the surface microlayer on the flux of nonconservative trace gases $\left(\mathrm{CO}, \mathrm{H}_{2}\right.$, $\mathrm{CH}_{4}, \mathrm{~N}_{2} \mathrm{O}$ ) across the ocean-atmosphere interface. J. Atmos. Chem. 1988, 6, 83-94. [CrossRef]

27. Upstill-Goddard, R.C.; Frost, T.; Henry, G.R.; Franklin, M.; Murrell, J.C.; Owens, N.J.P. Bacterioneuston control of air-water methane exchange determined with a laboratory gas exchange tank. Glob. Biogeochem. Cycles 2003, 17. [CrossRef]

28. Fitzwater, S.E.; Knauer, G.A.; Martin, J.H. Metal contamination and its effect on primary production measurements. Limnol. Oceanogr. 1982, 27, 544-551. [CrossRef] 
29. Beer, T. Beaufort wind scale. Encycl. Nat. Hazards 2013, 42-45. [CrossRef]

30. Schlitzer, R. Ocean Data View. Available online: http:/ / odv.awi.de (accessed on 21 September 2017).

31. Harvey, G.W.; Burzell, L.A. A simple microlayer method for small samples. Limnol. Oceanogr. 1972, 17, 156-157. [CrossRef]

32. Carlson, D.J. A field-evaluation of plate and screen microlayer sampling techniques. Mar. Chem. 1982, 11, 189-208. [CrossRef]

33. Grasshoff, K.; Kremling, K.; Ehrhardt, M. Methods of Seawater Analysis; John Wiley \& Sons: Hoboken, NJ, USA, 2009.

34. Garcia, H.E.; Gordon, L.I. Oxygen solubility in seawater-better fitting equations. Limnol. Oceanogr. 1992, 37, 1307-1312. [CrossRef]

35. R Development Core Team. R: A Language and Environment for Statistical Computing; R Foundation for Statistical Computing: Vienna, Austria, 2015.

36. Rahlff, J. Net community production and respiration of oxygen in the sea-surface microlayer, $1 \mathrm{~m}$ and $5 \mathrm{~m}$ depth during METEOR cruise M117, Baltic Sea and FALKOR cruise FK161010 Pacific Ocean. PANGAEA 2017. [CrossRef]

37. Hardy, J.T. Phytoneuston ecology of a temperate marine lagoon. Limnol. Oceanogr. 1973, 18, 525-533. [CrossRef]

38. Hardy, J.T.; Apts, C.W. The sea-surface microlayer-phytoneuston productivity and effects of atmospheric particulate matter. Mar. Biol. 1984, 82, 293-300. [CrossRef]

39. Del Giorgio, P.A.; Duarte, C.M. Respiration in the open ocean. Nature 2002, 420, 379. [CrossRef] [PubMed]

40. Pomeroy, L.R.; Sheldon, J.E.; Sheldon, W.M. Changes in bacterial numbers and leucine assimilation during estimations of microbial respiratory rates in seawater by the precision Winkler method. Appl. Environ. Microbiol. 1994, 60, 328-332. [PubMed]

41. Lorenzen, C.J. Extinction of light in the ocean by phytoplankton. ICES J. Mar. Sci. 1972, 34, $262-267$. [CrossRef]

42. Famielec, S.; Malinowski, M.; Brzychczyk, B.; Salamon, J. Present used methods for measuring dissolved oxygen concentration at wastewater treatment plants. Infrastrukt. Ekol. Teren. Wiej. 2015, 431-440. [CrossRef]

43. Carpenter, J.H. The accuracy of the Winkler method for dissolved oxygen analysis. Limnol. Oceanogr. 1965, 10, 135-140. [CrossRef]

44. Markfort, C.D.; Hondzo, M. Dissolved oxygen measurements in aquatic environments: The effects of changing temperature and pressure on three sensor technologies. J. Environ. Qual. 2009, 38, 1766-1774. [CrossRef] [PubMed]

45. Ziervogel, K.; D’Souza, N.; Sweet, J.; Yan, B.; Passow, U. Natural oil slicks fuel surface water microbial activities in the northern Gulf of Mexico. Front. Microbiol. 2014, 5, 188. [CrossRef] [PubMed]

46. Daly, K.L.; Passow, U.; Chanton, J.; Hollande, D. Assessing the impacts of oil-associated marine snow formation and sedimentation during and after the Deepwater Horizon oil spill. Anthropocene 2016, 13, 18-33. [CrossRef]

47. Song, Y.K.; Hong, S.H.; Jang, M.; Kang, J.H.; Kwon, O.Y.; Han, G.M.; Shim, W.J. Large accumulation of micro-sized synthetic polymer particles in the sea surface microlayer. Environ. Sci. Technol. 2014, 48, 9014-9021. [CrossRef] [PubMed]

48. Oberbeckmann, S.; Löder, M.G.J.; Labrenz, M. Marine microplastic- associated biofilms-A review. Environ. Chem. 2015, 12, 551-562. [CrossRef]

49. Sudhakar, M.; Doble, M.; Murthy, P.S.; Venkatesan, R. Marine microbe-mediated biodegradation of low- and high-density polyethylenes. Int. Biodeter. Biodegr. 2008, 61, 203-213. [CrossRef]

50. Tranvik, L.J.; Olofsson, H.; Bertilsson, S. Photochemical Effects on Bacterial Degradation of Dissolved Organic Matter in Lake Water. In Microbial Systems: New Frontiers, Proceedings of the 8th International Symposium on Microbial Ecology, Halifax, NS, Canada, 9-14 August 1998; Bell, C., Brylinsky, M., Johnson-Green, P., Eds.; Atlantic Canada Society for Microbial Ecology: Halifax, NS, Canada, 1999; pp. 193-200.

51. Wetzel, R.G.; Hatcher, P.G.; Bianchi, T.S. Natural photolysis by ultraviolet irradiance of recalcitrant dissolved organic matter to simple substrates for rapidbacterial metabolism. Limnol. Oceanogr. 1995, 40, 1369-1380. [CrossRef] 
52. Lee, E.; Noh, Y.; Hirose, N. A new method to produce sea surface temperature using satellite data assimilation into an atmosphere-ocean mixed layer coupled model. J. Atmos. Ocean. Tech. 2013, 30, 2926-2943. [CrossRef]

53. Williamson, C.E.; Zepp, R.G.; Lucas, R.M.; Madronich, S.; Austin, A.T.; Ballare, C.L.; Norval, M.; Sulzberger, B.; Bais, A.F.; McKenzie, R.L.; et al. Solar ultraviolet radiation in a changing climate. Nat. Clim. Change 2014, 4, 434-441. [CrossRef]

(c)

(C) 2017 by the authors. Licensee MDPI, Basel, Switzerland. This article is an open access article distributed under the terms and conditions of the Creative Commons Attribution (CC BY) license (http:/ / creativecommons.org/licenses/by/4.0/). 